International Journal of Current Advanced Research

ISSN: O: 2319-6475, ISSN: P: 2319 - 6505, Impact Factor: SJIF: 5.995

Available Online at www.journalijcar.org

Volume 6; Issue 4; April 2017; Page No. 3102-3103

DOI: http://dx.doi.org/10.24327/ijcar.2017.3103.0193

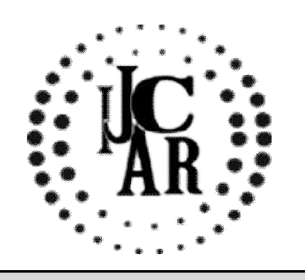

Research Article

\title{
MICRO SYNDROME IN AN ADULT
}

\section{Kannan R*., Prasanna Karthik S., Jagadeesan M and Mahendran Kumar K}

Department of General Medicine, Saveetha Medical College Hospital, Chennai, Tamilnadu, India

\section{A R T I C L E I N F O}

Article History:

Received $17^{\text {th }}$ January, 2017

Received in revised form $8^{\text {th }}$ February, 2017

Accepted $22^{\text {nd }}$ March, 2017

Published online $28^{\text {th }}$ April, 2017

\section{Key words:}

Micro syndrome, micro cornea, congenital

cataract, micro genitalia

\begin{abstract}
A B S T R A C T
Any Patient who presents with congenital cataract in the younger age group needs a thorough clinical examination. Our patient had mental retardation with micro ophthalmia, micro cornea, and micro genitalia, operated for congenital cataract in the younger age. So a diagnosis of micro syndrome was made due to the predominant ocular manifestations.
\end{abstract}

Copyright $\bigcirc 2017$ Kannan $\boldsymbol{R}$ et al. This is an open access article distributed under the Creative Commons Attribution License, which permits unrestricted use, distribution, and reproduction in any medium, provided the original work is properly cited.

\section{INTRODUCTION}

\section{Case report}

A twenty year old female came to the medical outpatient department for the treatment of gastritis. She had past history of cataract, both eyes got operated for cataract at the age of two years. There was history of delayed motor and mental milestones since childhood. She attained menarche at the age of fourteen years, periods were irregular initially and with a present history of amenorrhea for the past four years. On clinical examination She had high arched palate, mental retardation, stunted growth, short stature, under weight, micro ophthalmia, small cornea-micro cornea $(9 \mathrm{~mm}$ in both meridians),

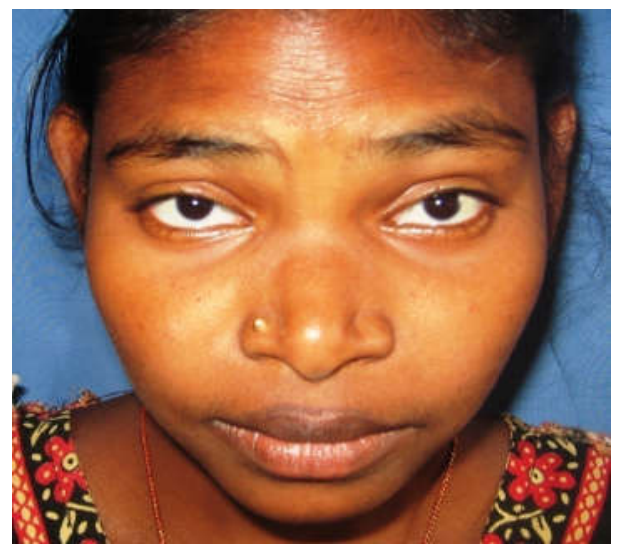

Figure 1 microophthalmia and micro cornea

\section{*Corresponding author: Kannan R}

Department of General Medicine, Saveetha Medical College Hospital, Chennai, Tamilnadu, India (figure.1) both eyes-aphakic (bilateral congenital cataract operated) with small head-microcephaly. The secondary sexual characters, and external genitals were normal Investigations revealed Hb-9 gms, blood hemogrammicrocytic hypochromic anemia.Thyroid function tests, renal function tests, blood sugar, urine examination, ECG, serum calcium-were all within normal limits. CT-brain-normal. No evidence of intracranial calcification or agenesis of corpus callosum. Buccalsmear for Barr body-positive. Audiogram normal study. Urine for galactose-negative. Ultrasonogram and CT scan of abdomen revealed small atrophied uterus and absent ovaries), (figure .2)

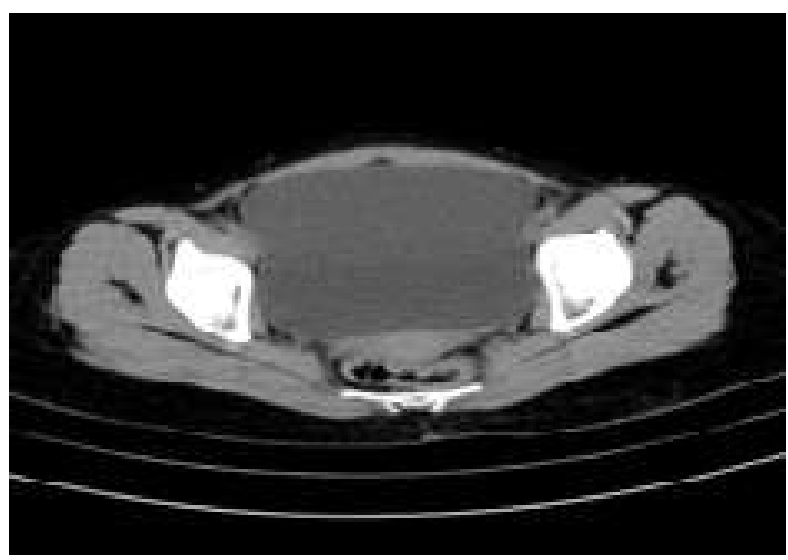

Figure 2 Atrophied uterus \& absent ovaries

Since she had Mental retardation, congenital cataract, micro cornea, microgenitalia a diagnosis of micro syndrome was made. 


\section{DISCUSSION}

Micro syndrome was first described by Wardburg (1). Micro syndrome is more commonly seen in children than in adults.(2). Micro syndrome is an autosomal recessive disorder characterized by ocular and neuro developmental defects and microgenitalia. (3) The pathology is due to abnormal neurotransmitter vesicular transport and exocytosis. In the literature few cases of micro syndrome were reported in children and younger age group rather than adults. $(4,5)$

Ocular findings are the most reliable diagnostic signs of micro syndrome. The clinical features are as follows -congenital cataract, microcornea, microphthalmia, microcephaly, mental retardation, atonic pupils, optic atrophy, and corpus callosum hypoplasia.(1). Congenital cataract is the most common symptom of the disease. Our patient had congenital cataract in childhood and it was operated in the younger age. Other clinical features include dysmorphic facies, high arched palate and ear abnormality which were present in our patient.

The causes of congenital cataract are viral infection-Rubella, sporadic, galactosemia, hypoparathyroidism, Down's syndrome, Trisomy syndromes, Cri du chat syndrome, Micro syndrome, toxins, drugs, irradiation neurofibromatosis, juvenile chronic arthritis and steroid therapy. The Differential Diagnosis for Micro syndrome are COFS syndrome-cerebrooculo-facio-skeletal syndrome-severe brain atrophy and calcification can occur. $(6,7)$. NHS -Nance Horan Syndrome (XLD)-dental and facial anomalies are present, mental retardation can be seen in most of the cases. She was clinically diagnosed to have micro syndrome and was treated symptomatically and she is under regular follow up.

\section{CONCLUSION}

Our patient had clinical features suggestive of micro syndrome in the form of microcephaly, microophthalmia, microcornea, and microgenitalia. Ocular finding are the most reliable diagnostic signs of micro syndrome. So micro syndrome should be considered in any patient with congenital cataract and microophthalmia and micro cornea with mental retardation.

\section{References}

1. Warburg M, Sjö O, Fledelius HC, Pedersen SA. Autosomal recessive microcephaly, microcornea, congenital cataract, mental retardation, optic atrophy, and hypogenitalism. Micro syndrome. Am J Dis Child. 1993; 147:1309-12.

2. Prabhjot K S, Premalatha R, and Sarala S Warburg micro syndrome in siblings from India $J$ Pediatr Neurosci. 2016 Jan-Mar; 11(1): 83-85. doi: 10.4103/1817-1745.181255

3. Abdel-Salam GM, Hassan NA, Kayed HF, Aligianis IA. Phenotypic variability in Micro syndrome: Report of new cases. Genetic Counseling (Geneva, Switzerland) 2006; 18:423-35.

4. Yüksel A, Yesil G, Aras C, Seven M. Warburg micro syndrome in a Turkish boy. Clin Dysmorphol. 2007;16:89-93

5. Yildirim MS, Zamani AG, Bozkurt B. Warburg micro syndrome in two children from a highly inbred Turkish family. Genet Couns. 2012; 23:169-74.

6. Graham JM, Hennekam R, Dobyns WB, Roeder E, Busch D. MICRO syndrome: An entity distinct from COFS syndrome. American $J$ Med Genetics Part A. 2004; 128:235-45.

7. Pena SD, Shokeir MH. Autosomal recessive cerebrooculo-facio-skeletal (COFS) syndrome. Clin Genet. 1974; 5:285-93.

\section{How to cite this article:}

Kannan R et al (2017) ' Micro Syndrome In An Adult ', International Journal of Current Advanced Research, 06(04), pp. 3102-3103. DOI: http://dx.doi.org/10.24327/ijcar.2017.3103.0193 